\title{
Ecological study of social organization in the Great Tit, Parus major L. II. Formation of the basic flocks*
}

\author{
Takashi Saitou**
}

\section{Introduction}

In the Great Tit, Parus major L., the flocks are found from early summer to early spring and can be classified into three types according to the differences in the period of occurrence and the composition (Saitou 1978). The first type is a family flock which usually occurs from late May to early July and breaks up about a month after the young left the nest. The second is a summer flock. The young form the summer flock by themselves after becoming independent of their parents while the adults remain on or near their previous breeding territory during July and August. The third is a basic flock of constant composition. The adults and the young not related to the adults by blood gradually form the basic flocks from September onward and most of the basic flocks are formed by the middle of October.

Since the formation of the basic flock takes place through such successive process, it is necessary for understanding the characteristics of the basic flock to investigate the process of its formation. The formation of winter flocks in the genus Parus has been described briefly in the Great Tit (Hinde 1952), the Black-capped Chickadee, P. atricapillus (Glase 1973) and the Carolina Chickadee, P. carolinenses (Brewer 1961, Dixon 1963). Since the adults of these species usually remain on or near their previous breeding territory even after the breeding season and then are joined by the young to form a flock, it seems that the key point of flock formation is the movement of the young after having become independent of their parents. However, few attempts have been made to study the movement of the young from late summer to early autumn.

This paper describes the formation of the basic flock based on observations in the summer and autumn of 1970 . The aim is to clarify movement of the young from dispersal to settlement in a restricted area and to determine factors relating with the association of members in the basic flock.

\section{Study area}

The field work was done in the Akasaka Palace, Tokyo, Japan. The study area (Fig. 1)

\footnotetext{
* This paper is a part of Dr. Sci. thesis submitted to the Tôhoku University.

** Institute of Biological Sciences, The University of Tsukuba, Sakura-mura, Ibaraki 300-31, Japan.
} 
consisted of 21.7 ha of mixed evergreen and deciduous broad-leaved forest, another 12.4 ha with open lawn and grassland, and 2.3 ha of pond. The composition of the forest was described by Saitou (1978). In the forest, nesting boxes had been provided at a density of about ten per ha and most of the pairs bred in the nesting boxes.

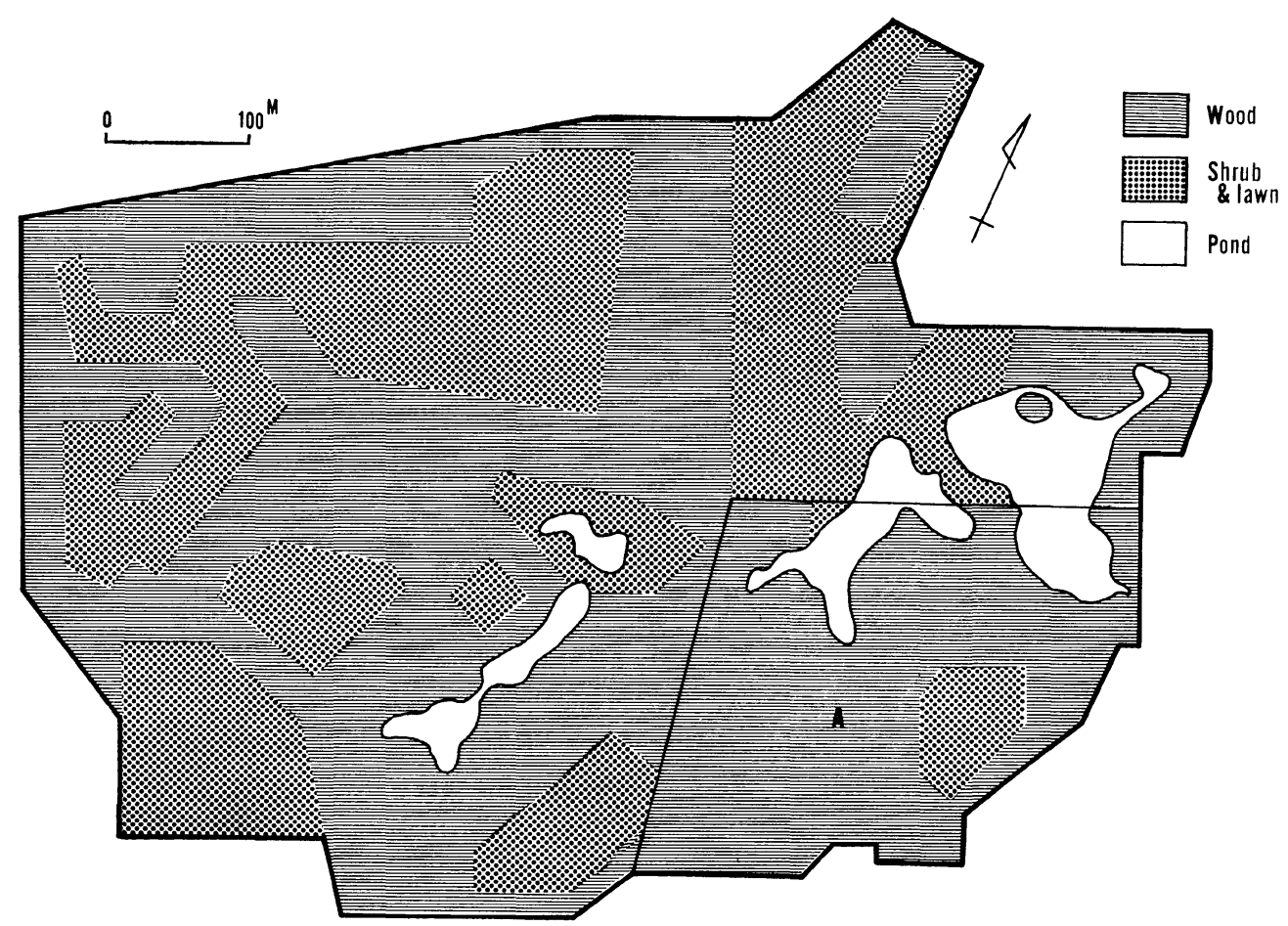

Fig. 1. Study area. A is the main study area of flock formation.

The study area was fenced with a stone wall of about three meters height and surrounded on the south side by residental area and on other three by parkland. Although some Great Tits immigrated into the study area from the surrounding, virtually the whole population consisted of the birds that had bred or were born in the study area.

\section{Methods}

In the study area, nearly all of the birds were marked individually with colour rings. The method of marking was described in detail by Saitou (1978). The case history of each marked bird was recorded from the birth or capture to the death or disappearance, so that their previous history was known.

Observations were made on the family and summer flocks form late May through the middle of September and focussed on the basic flock from late September onward. A flock 
or individual was followed for at least twenty minutes and its movements were plotted directly on a $1: 2500$ scale field map. Many such observations were then superimposed onto one map and a perimeter was drawn around the home range of each flock or individual. The size and composition of each flock were recorded and the members of the flock were identified by their colour rings in each observation. The territory was determined by connecting points at which chases and boundary clashes occurred within the home range of the pair.

The process of flock formation was studied mainly in the south-east part of the study area (A in Fig. 1). The flocks or individuals were observed every other day from July to September.

\section{Results}

The formation of a basic flock takes place through a successive process. A general description of flock formation is given, illustrated by the behaviour of adults and young belonging to the basic flock $I$ in the autumn of 1970 . This flock was observed in the southeast part of the study area and consisted of five adults and five young (Table 1).

Table 1. Members of the basic flock I. The adults and young are not related by blood. Symbols: $M$, male. F, female. Age, year old. Male and female with the same asteriks are mates of previous breeding pair.

\begin{tabular}{ccc}
\hline Member & Sex & Age \\
\hline I-3* & F & 3 \\
I-4* & M & 2 \\
I-10** & M & 1 \\
I-14** & F & 1 \\
I-15 & M & 1 \\
I-16 & M & 0 \\
I-17 & M & 0 \\
I-18 & M & 0 \\
I-19 & F & 0 \\
I-20 & M & 0 \\
\hline
\end{tabular}

The family flocks are usually found from late May to early July, with the earliest ones of the first broods in the middle of May and the latest ones of the second broods in early August. The parents and their young remain on their territory for the first few days after the young left the nest, but then trespass into the territories of neighbouring pairs and move about the forest by themselves. 
Within a week or ten days after the young left the nest, most of the family flocks forage nearly all over the study area. They are observed at a long distance from their nesting site. In 1970, the greatest distance from their nesting site to which the family flock was observed within the study area ranged from $200 \mathrm{~m}$ to $600 \mathrm{~m}$, with an average of $310 \pm$ $120 \mathrm{~m}$. Assuming the mean greatest distance as a radius of home range, it is estimated that the home range of family flocks are, in average, about 30 ha. But this figure is an estimate upon the greatest distance observed within the study area. In fact, most of the family flocks wandered away frequently to the surrounding areas during observations and disappeared for a long time in the day. This is the reason why the actural size of home range could not be measured. The actual home range of family flocks may be larger than the estimated one.

The family flocks gradually break up within three to four weeks after the young left the nest. The young disperse soon after having become independent of their parents. Since there is no indication that the parents actively drive their young away, it is probable that the dispersal of the young is due to an innate tendency to move, independent of the environment situation (Hinde 1952).

The young scatter all over the forest. At first, the young usually associate and move with other family flocks, but they gradually associate with each other to form a summer flock. In the south-east part of the study area, five young belonged to the basic flock I later appeared for the first time between 7 and 24 days after their family flocks were lastly observed (Table 2). The average interval of such appearance in a total 15 young in this

Table 2. Young of the basic flock I and date when the young appeared for the first time in the south-east part of the study area. A, the young left the nest. B, the family flock was lastly observed. C, the young appeared for the first time in the area. I-18 and 19 are the young of the same brood. I-17 is the immigrant from the surrounding area.

\begin{tabular}{cccc} 
A & \multicolumn{3}{c}{ Date } \\
Young & A & B & C \\
\hline I-16 & May 28 & Jun. 26 & Jul. 3 \\
I-17 & - & - & Jul. 8 \\
I-18 & May 25 & Jun. 21 & Jul. 10 \\
I-19 & May 25 & Jun. 21 & Jul. 23 \\
I-20 & May 23 & Jun. 24 & Jul. 21 \\
\hline
\end{tabular}

area was $22 \pm 10$ days, ranging from 7 to 39 days. After appearing in this area, the young were nearly always observed singly or in the summer flocks foranging over there. It seems that the young settle in a large, but restricted area within a relatively short period after 
having become independent of their parents.

The summer flock forages over a wide range. It breaks up into smaller parts which unite again into larger ones reatedly within a day. Moreover, the size and members of the flocks change very frequently. This makes it difficult to define and measure the home range of the summer flock as a whole. Then, the home range of each young was measured. The home range of young in July and August is called "summer range", whereas that in September "autumn range"

Although the whole home range of the family flock could not be measured, the summer ranges of young belonged to the basic flock I later overlapped the observed home ranges of their family flocks. The summer range (Fig. 2) was very larger than the home range of

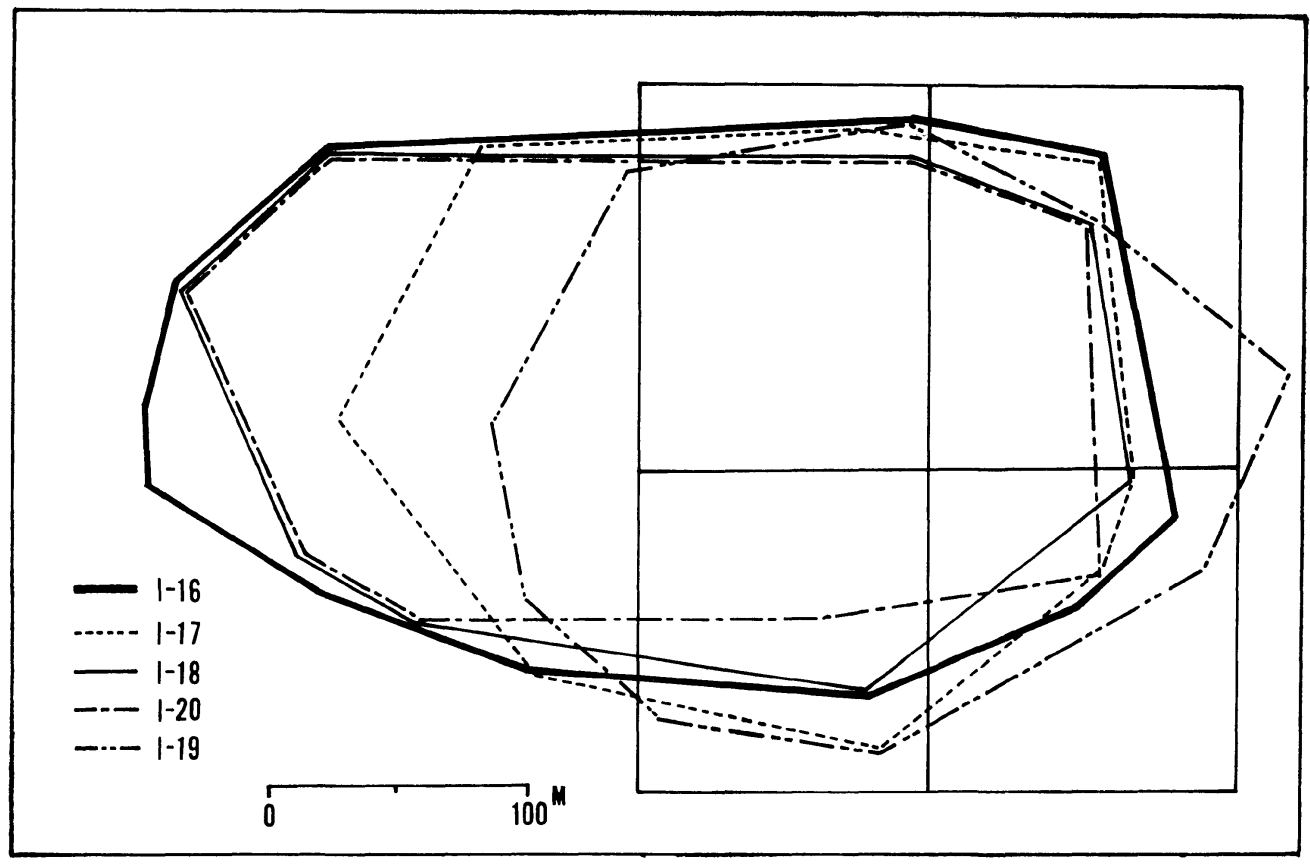

Fig. 2. Summer ranges of the young which belonged to the basic flock I.

adults (Fig. 3) and overlapped not only each other extensively, but also the home ranges of adults. Excepting the home ranges of two previous breeding pairs and one widowed adult belonged the basic flock I later, they overlapped those of five previous breeding pairs and nine widowed adults. The young were associated with each other more tightly than adults (Fig. 4-A), but they were not always observed together, even if the difference of appearance in this area is taken into consideration (Table 2). All of the young were sometimes found in the same flock, but some of them usually moved with one flock and the rest with another. Also, the young spent singly some of their time. There was no tendency 


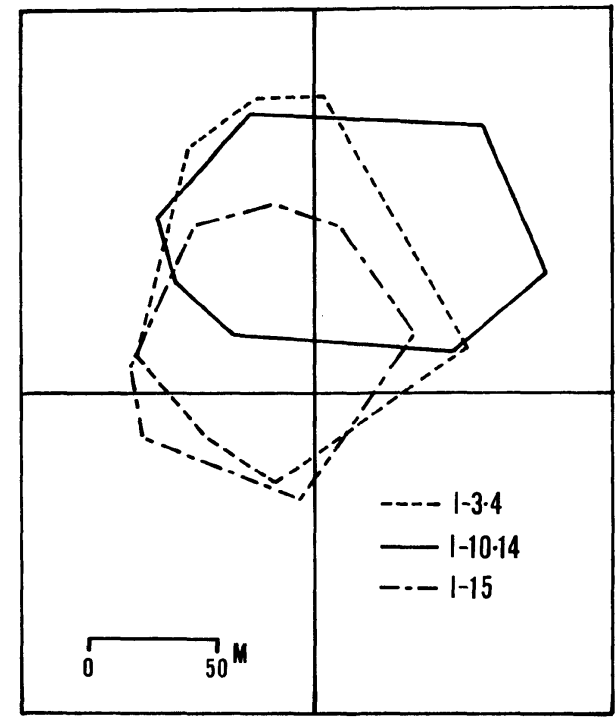

Fig. 3. Home ranges of the adults in July and August.

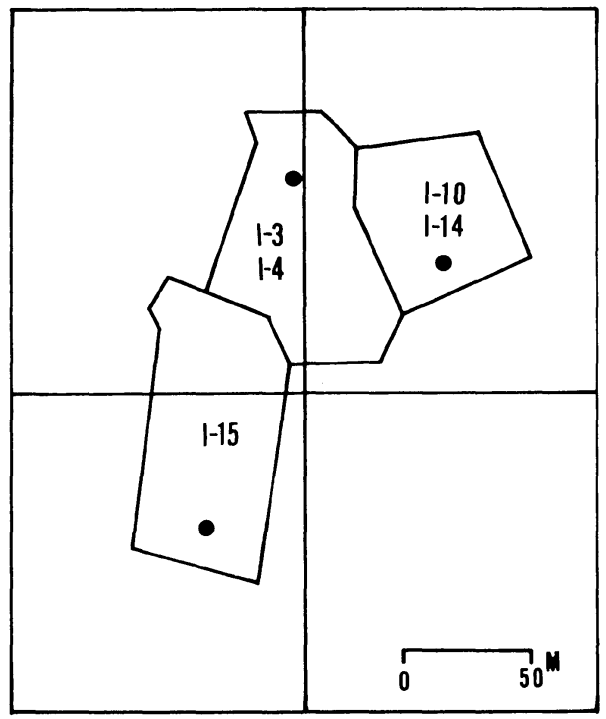

Fig. 5. Breeding territories of adults in the spring of 1970 . Black circle, nesting site.

Fig. 4. Association of adult and/or young before the formation of the basic flock I. A, in July and August. B, in September. Symbols indicate the percentage of bird when the bird or previous breeding pair was seen in association with a particular bird to the total number of observations. The percentage is caluculated as follow; in the case of I-16 and I-19 in B, I-19 was observed together with $\mathrm{I}-16$ in 13 times. The total number of observations in I-19 was 13 times so that the percentage of association with I-16 was $100(13 / 13)$. On the other hand, I-16 was observed together with I-19 in 13 times. The total number of observations in I-16 was 24 times, so the percentage of association with I-19 was 54.1 (13/24). Parenthesis indicates number of observation when the bird or previous breeding pair was seen singly. M, male. F, female. Age, year old. 


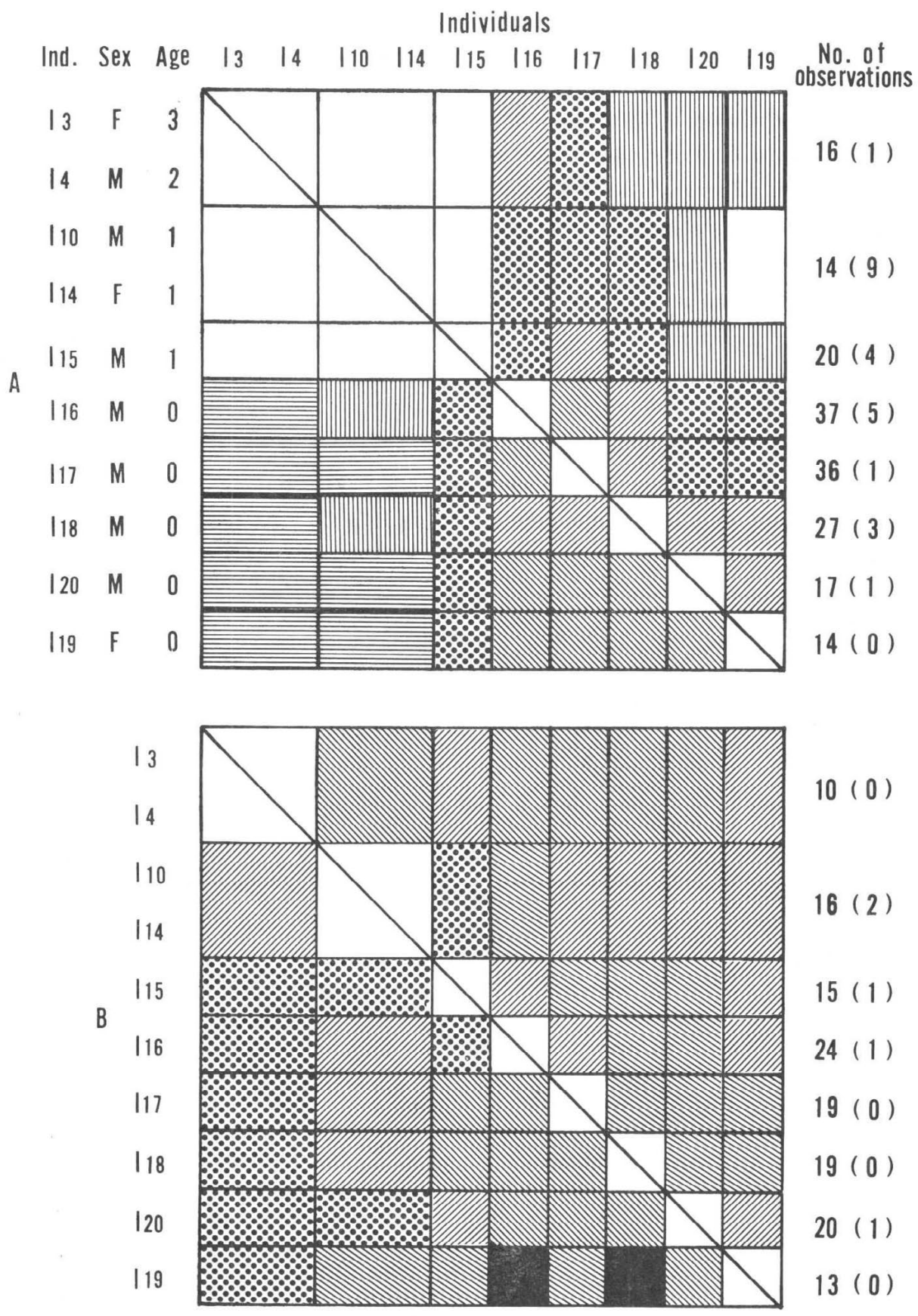

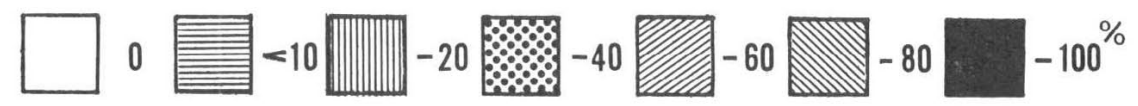


for the young to be associated more closely with the adults belonged to the basic flock I later than other adults whose home ranges overlapped the summer ranges of the young.

On the other hand, the adults remain on or near their previous breeding territory even after the breeding, although territorial behaviour is latent at this time. Making a comparison between Fig. 3 and 5, it is clear that the adults restricted their movements to their previous breeding territory. The adults start to moult at about the time when their last young reached independence. They are inactive and of ten observed singly or with the mate of previous breeding pair during the moult. The moulting adults sometimes join the summer flock only when it is within their previous breeding territory, but drop out near the boundary of the previous breeding territory. The adults were observed together with the young to some extent during July and August, but they did not foraged together with the neighbouring adults (Fig. 4-A).

The summer flocks begin to break up in September. And the young gradually show a preference for a particular part of their summer range. The autumn ranges of young (Fig. 6) were considerably smaller than the summer ranges (Fig. 2). At the same time, the degree

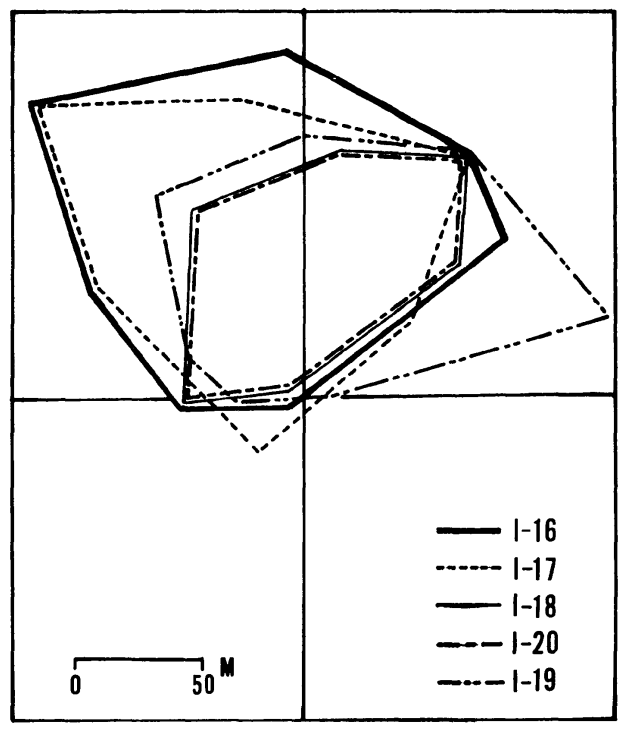

Fig. 6. Autumn ranges of young.

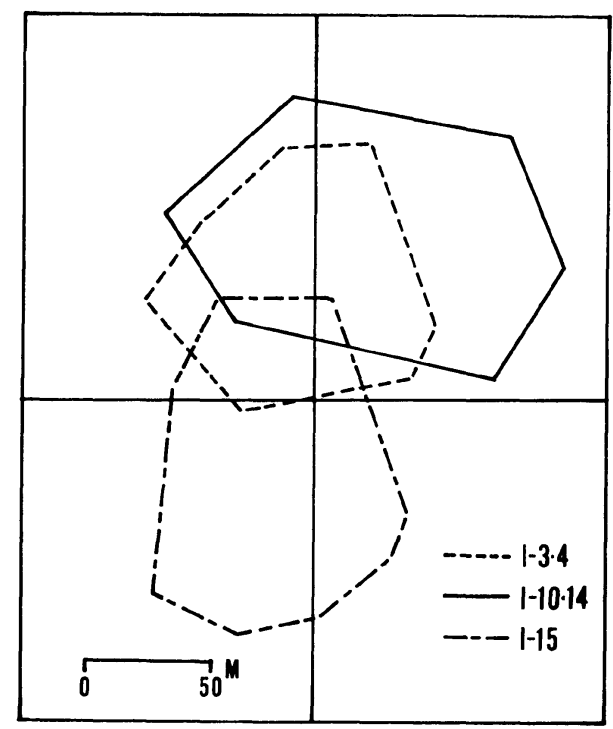

Fig. 7. Home ranges of adults in September.

of association among the young in September (Fig. 4-B) became higher than that in July and August (Fig. 4-B). Also, the behaviour of adults changed in September. The home ranges of adults overlapped each other extensively (Fig. 7). Moreover, the adults became to be observed together with the neighbouring adults (Fig. 4-B).

The relation between adult and young also changed in September. First, the autumn ranges of the young overlapped only with a few home ranges of adults belonged to the 
basic flock I later (Fig. 6 and 7). Secondly, the association of the adults and young was much more strong (Fig. 4-B), as compared with Fig. 4-A. From this time onward, the number and members of the young in this area became more and more constant, and the adults and young were always observed together. Thus, the basic flock I was formed in late September. In the study area, such process was observed in other basic flocks and most of the basic flocks were usually formed by the middle of October every year.

\section{Discussion and conclusion}

In the process of flock formation, the adults remain on or near their previous breeding territory even after the breeding and then are joined by the young to form a basic flock, so that the movement of the young is important to the formation of basic flocks. There are three stages in the movement of the young after having become independent of their parents; the establishment of summer and autumn ranges, and the final association with adults in an area.

With respect to the period of establishment of summer ranges, the young appeared for the first time in a particular area within about a month after their family flocks were lastly observed and then were observed nearly always in the area. Making allowance for the time lag between the last observation of the family flock and the actual independence of the young, it is concluded that most of the young must establish their summer range within a relatively short period after having become independent of their parents.

The autumn ranges are established within the summer ranges by autumn. Kluijver (1951) and Hinde (1952) said that many young settled in a restricted area by their first autumn, but both authors did not clearly show when most of the young settled. From the observation of roosting birds in nesting boxes, Kluijver (1951) described briefly that some young were still wandering about during November, even in December. Also, Hinde (1952) noted that not all young became sedentary as early as November, but that he did not study the movement of the young between July and November.

In the study area, the number and members of the young observed in the same area became more and more constant from September onward and then a basic flock was formed with these young and adults in the area. The membership of the basic flock is usually established by the middle of October (Saitou 1978), even though a few young continued to wander about till early November. As the basic flocks are constant in membership throughout the winter, the period when the membership of the basic flock is established can be regarded as the period of final settlement of young in their autumn range. Hence it is concluded that most of the young settle in their autumn range by the middle of October.

With respect to the area that the young establish for their summer or autumn ranges, Kluijver (1951) found that the greatest distance from the nesting site to which the family flock wandered was from $200 \mathrm{~m}$ to $1 \mathrm{~km}$, and that it was about equal to the distance between 
the birth place and the first breeding place of young in a rather poor broad-leaved and conifer wood. Hence, he suggested that the young would select their range within the home range of their family flocks.

In the present study, the greatest distance from the nesting site to which the family flock was observed within the study area was, in average, $310 \mathrm{~m}$, ranging from $200 \mathrm{~m}$ to $600 \mathrm{~m}$ in the mixed evergreen and broad-leaved forest. This figure is slightly different from that given by Kluijver (1951) and the difference is probably due to difference of the vegetations. In the study area, most of the family flocks wandered away frequently to the surrounding areas, so the actual greatest distance seems to be longer than the observed one. Also, the distance from the birth place of the young to the feeding activity center of the flock range in the basic flock to which the young belonged was, in average, $300 \mathrm{~m}$, ranging from $20 \mathrm{~m}$ to $710 \mathrm{~m}$ (Saitou 1978). The average value of the former is equal to that of the latter. The young join the basic flock formed in their autumn ranges and the autumn ranges are established within the summer ranges. Moreover, the summer ranges of the young belonging to the basic flock I overlapped the observed home ranges of their family flocks. This facts reveals that the young probably established their summer or autumn ranges within the home range of their family flock.

The association of young and adults is observed since young formed to summer flock. The summer ranges are considerably larger than the home ranges of adults and overlap many home ranges of adults. The young are associated with every adult whose home range overlaps the summer ranges of the young, but only while the flock is within the home range of each adult. Therefore, the association of the young and adults in this period is a loose and temporary one.

On the other hand, the behaviour of young changes when they establish their autumn range. The summer flocks disintegrate and change to each cohesive association of young whose autumn ranges overlap in an area. As compared with the summer ranges, the autumn ranges are reduced in size and overlap only with a few home ranges of adults, so that the association of the young and adults in the area also becomes stronger than it has been previously. A basic flock is formed by these birds. Thus, the process of basic flock's formation is closely related with the extensive overlap of home ranges between individuals.

Taking the process of flock formation in consideration, the adults remain on or near their previous breeding territory even after the breeding and then the young settle in the area as their autumn range. Consequently, the home ranges of the adults and the autumn ranges of the young overlap extensively as a whole. Therefore, it is concluded that the adults are regarded as the nucleus of the basic flock because of their prior occupancy, and that the members of a basic flock are primarily associated with each other by their site attachment since the basic flock is formed by the indiciduals whose home ranges overlap. 


\section{Acknowledgement}

I am much indebted to Professor Y. Kurihara of the Tohoku University, for his discussion and criticism on the present study. I express appreciation to Dr. J. Mishima of the University of Tsukuba for his advice and encouragement. I wish to thank Professor M. Uramoto of the Wakô University and Dr. M. Nishihira of the Kyoto University, who kindly read and offered critical comments of this paper. I am grateful to Mr. N. Abe for his discussion and to Miss M. Asakawa for her assistance of 1972-73. I would also like to thank Mr. S. Ohori for his assistance of 1973 onward and his discussion. Finally, I wish to express my thanks to the chamberlains of the Household of the Akasaka Palace, who gave me many kind of help.

\section{Summary}

1. This paper describes the formation of basic flocks, particularly the movement of the young from the dispersal to the final settlement in a restricted area, and discusses the factors relating with the association of members in a basic flock. The field work was carried out in the summer and autumn of 1970 at the Akasaka Palace, Tokyo, Japan. The study area of about 37 ha consisted of mixed evergreen and deciduous broad-leaved forest. In the study area, virtually all of the birds were marked individually by colour rings and their previous history was known.

2. The formation of the basic flocks took place through a successive process; the establishment of summer and autumn ranges of young, and the final association of the young and adults in an area. The young were associated with each other to form the summer flock when the family flocks broke up. Most of the young established their summer range within a relatively short period, usually about a month, after having become independent of their parents.

3. Forming the summer flocks, the young gradually showed a preference for a particular part of their summer range. The number and members of young observed in the same area became more and more constant from this time onward. By the middle of October, most of the young established the autumn range within their summer range. It is considered that the young establish their summer or autumn ranges within the home range of their family flock.

4. The adults remained on or near their previous breeding territory even after the breeding, and then the young settled in the area as the autumn range. Consequently, the home ranges of the adults and the autumn ranges of the young overlapped extensively as a whole. And a basic flock was formed by these birds. Therefore, it is concluded that the formation of basic flocks are closely related with the period of the extensive overlap of home ranges between individuals, and that the members of a basic flock are primarily associated with each other by their site attachment.

\section{Reference}

Brewer, R. 1961. Comparative notes on the life history of the Carolina Chickadee. Wilson Bull. $23: 348-373$.

Dixon, K. L. 1963. Some aspects of the social organization of the Carolina Chickadee. Proc. Int. Ornith. Congr. 13:291-299.

Glase, J.C. 1973. Ecology of social organization in the Black-capped Chickadee. Living Bird $17: 235-265$.

Hinde, R. A. 1952. The behaviour of the Great Tit (Parus major) and other related species. Behaviour Suppl. $2: 1-201$.

Kluijver, H.N. 1951. The population ecology of the Great Tit, Parus m. major L. Ardea 39 : $1-135$. 
Saitou, T. 1978. Ecological study of social organization in the Great Tit, Parus major L. I. Basic structure of the winter flocks. Jap. J. Ecol. $28: 199-214$.

\section{シジュウカラの社会組織に関する生態学的研究 II. 基本群の形成 \\ 斎藤 隆史}

1. 本論文は基本群の形成, 特に若鳥の分散から特定の地域への定着丈での動向について記述し, 基本 群の構成員の結び付きに関する要因を論じたものである。調查は1970年の夏期および秋期に赤坂御用地に おいて行った。

2. 基本群の形成は若鳥の夏期および秋期行動圈の選定，若鳥之成鳥の最終的な結び付き々いら三つの 過程を経て行われる。若鳥は家族群の崩壊後, 若鳥だけの夏期群を形成し, 親鳥からの独立後, 約一ケ月 以内に夏期行動圈を選定する。

3. 夏期群を形成しながら，若鳥は次第にその活動を夏期行動圈内の特定の場所に集中しはじめ，同一 地域で観察される若鳥の構成が一定になってくる。大部分の若鳥は10月中旬頃までに秋期行動圈を選定す るが，夏期および秋期行動圈は家族群の行動圈内に選定されると考兄られる。

4. 成鳥は繁殖後も元のテリトリーを中心とした地域に留まっていて，その後に若鳥が成鳥の留まって いる地域を秋期行動圈として選定する。その結果，成鳥の行動圈と若鳥の秋期行動圈が重複することにな り，これらの個体によって基本群が形成される。

5. したがって，基本群は行動圈が重複する個体から形成され，構成員間の結び付きは主に行動圈の重 複によっていると考えられる。

筑波大学生物科学系, 茨城県新治郡桜村（而300-31） 